\title{
REGENERATION OF BALSAM FIR AND SPRUCE ABOUT FIFTEEN YEARS FOLLOWING RELEASE BY SPRUCE BUDWORM ATTACK ${ }^{1}$
}

\author{
BY R. E. FYE AND J. B. THOMAS ${ }^{2}$
}

R. E. Fye graduated from Iowa State University (B.S.) in entomology in 1949, from Washington State University (M.S.) in 1951, and from the University of Wisconsin (Ph.D) in 1954. From 1954 to 1955 he was an assistant entomologist at the New Mexico State University, doing research in field and forage crops. In late 1955 he moved to the U.S.D.A. Cotton Insects Section, working from laboratories at Stoneville, Miss., and Florence, S.C. He headed the latter laboratory from February, 1958, to November, 1959. He has been employed at the Sault Ste. Marie Forest Insect Laboratory since June, 1960.

\section{$A B S T R A C T$}

Regeneration plots were established near Laniel, P.Q., and in the Black Sturgeon and Cedar Lake areas of northwestern Ontario in 1950 to study the origin and development of regeneration in stands devastated by the spruce budworm. Results of tallies in 1950 and 1955 have been published, and this paper presents subsequent changes up to 1962. New balsam fir and spruce seedlings continue to become established on favourable seed beds in stands where seed trees survived the budworm outbreak. Some advanced growth, developing on the plots since the overstory was removed, began producing seed in 1962, although roadside trees of similar age and size were producing seed earlier. Balsam fir and spruce seedlings released by the budworm outbreak have grown rapidly, and are now retarding the height growth of some of the reproduction. The ratios of balsam fir to spruce reproduction calculated in 1950, 1955, and 1961 show considerable fluctuation within the same plots. Nevertheless, the general trend toward a higher proportion of balsam fir in the reproduction than in the original stand of trees, which was established before the spruce budworm outbreak, has remained virtually unaltered.

\footnotetext{
${ }^{1}$ Contribution No. 950, Forest Entomology and Pathology Branch, Department of Forestry, Ottawa, Canada.

${ }^{2}$ Forest Insect Laboratory, Sault Ste. Marie, Ontario. Biographical reference for J. B. Thomas in Forestry Chronicle 34:307, 1958.
} 


\section{INTRODUCTION}

Regeneration studies have been conducted since 1950 in three areas, Laniel, P.Q., adjacent to the northeastern boundary of Ontario, and Black Sturgeon and Cedar Lakes in northwestern Ontario. Severe spruce budworm (Choristoneura fumiferana Clem.) outbreaks occurred in all three regions in the previous decade. The spruce budworm infestation in the Laniel area reached a peak in 1941 and 1942, and had largely subsided by 1947. The population was at a peak between 1945 and 1947 at Black Sturgeon Lake, but collapsed by 1949 . Tree mortality at Cedar Lake was caused by more prolonged exposure to less severe defoliation. The budworm outbreak was still in progress in this area when the regeneration plots were established, declining to endemic levels by 1956 , at which time mortality of balsam fir (Abies balsamea (L.) Mill.) was almost complete on the regeneration plots.

Trends in forest succession during the first decade following devastation by the budworm in western Quebec and northwestern Ontario were discussed by Ghent et al. (1957). In a second paper, Ghent (1958) elaborated on age, height growth, and related studies of balsam fir seedlings, and in a third paper Ghent (1963 and in press) discussed problems of sampling precision and seedling distribution relating to regeneration surveys. These papers were based on plot tallies in 1950 and retallies in 1955. Following the decline of the budworm outbreak, much regeneration developed from residual trees, but the rapid increase in height of balsam fir, white spruce (Picea glauca (Moench) Voss), and black spruce (P. mariana (Mill.) B.S.P.) in some stands suggested that these young, open-growing trees may soon. produce seed. The plots were therefore retallied in mid-summer, 1961, to obtain up-to-date information on present regeneration and advanced reproduction so that in future the importance of seed produced by the younger trees could be assessed in relation to seed production by residual trees.

The rapid development of the advanced growth since 1955 also indicated that competition for space was intensifying, and that those trees destined to form the next merchantable stand were beginning to assert themselves. This situation underlined the importance of obtaining figures on height distribution of the reproduction at this particular stage in the development of the forest. These data are therefore placed on record here as a link between the seedling stage and the approaching stratification of the stands into dominant, codominant, intermediate, and suppressed trees.

\section{METHODS}

The regeneration plots, described by Ghent et al. (1957), ranged in size from 0.3 to 1.6 acres. The plots were divided into one-square-chain blocks, and 10 randomly selected milacre quadrats were sampled in each block. The milacre quadrats were delineated by 6.5-foot strips of plywood placed between the wire corner stakes. In addition to facilitating the routine location of corner stakes, these strips permitted approximate location of any corner from which the original stake was missing, and the tally was made on the basis of the estimated point.

\footnotetext{
${ }^{3}$ Interference from road and park construction and logging operations necessitated changes in the size of the following plots: A-4 reduced from 16 to 12 square chains; B-2 and B-8 reduced by three and two square chains respectively.
} 
Stems of all species on the quadrats were tallied by height or diameter classes. Fir and spruce seedlings that germinated in 1961 (henceforth referred to as first-year seedlings) were recorded separately to place this most recent crop of seedlings on file. The remaining stems were tallied according to the following height scale: $0-6.5^{\prime \prime}, 6.6-12.5^{\prime \prime} ; 12.6-18.5^{\prime \prime} ; 2^{\prime}$; and thereafter by 1 -foot intervals up to 7 feet. Balsam fir and spruce stems 8 feet in height were almost invariably at least 0.5 inches in diameter at breast height, and all stems over 7 feet were accordingly placed in the appropriate diameter class.

\section{Apparent Trends in Forest Succession}

Trends in balsam fir content of the forest succession during the 10 years following devastation of the overstory are summarized in Table 4 of Ghent et al. (1957). Table 1 of this paper is a recapitulation of the ratios of the stems per acre of balsam fir to spruce in the original mature stand, and of the reproduction tallied in 1950, 1955, and 1961. It should be noted that in 1950, at the time the stand composition was determined, the figures for the original stand included all dead trees 1 inch and over d.b.h. This accounted for almost 100 per cent of the balsam fir trees in many plots. Living trees up to 7 feet in height were defined as the reproduction in 1950 , but by 1955 and 1961, some of the reproduction had reached 3 inches in diameter. For purposes of comparison, however, these larger stems have been retained in the reproduction class.

Probably the most striking feature revealed by the 1961 data is the general decline from 1955 in the apparent proportion of balsam fir to spruce reproduction. Whereas all seven Laniel plots showed an increased ratio of balsam fir to spruce in 1955, this trend had been reversed in five of the plots by 1961. One plot at Black Sturgeon Lake contains no spruce, but the ratio in favour of balsam fir reproduction is decreasing in all but one of the remaining 12. Even in this one exception, the ratio changes to a decreasing proportion of balsam fir if the exceptionally large number $(19,180 /$ acre) of first-year seedlings is removed from the calculations. A slight reversal from the general situation is indicated at Cedar Lake, however, there being one fewer with a decreasing proportion of balsam fir than in 1955. This is thought to be of little consequence since balsam fir is relatively weaker in the western (site region $4 \mathrm{~S}$ ) area according to Hills (1959).

The ratios of balsam fir to spruce reproduction in 1950, 1955, and 1961 have been compared to the proportions of the two species in the original stand of trees in 1950, and the apparent trends, are listed in columns 6, 7, and 8 of Table 1. A summation of these columns shows that the total number of plots with an "increasing" or "decreasing" trend has remained almost the same at each tally. The trend toward an increasing proportion of balsam fir in the reproduction was established before the spruce budworm outbreak, and this trend has remained virtually unaltered.

Changes in seedling density from 1955 to 1961 and an appreciation of the density of seedlings established in 1961 (Table 2) may help to explain the changes in the apparent trends of stand development. In most plots, both balsam fir and spruce were more numerous in 1961 than in 1955, 
TABLE 1

APPARENT TRENDS OF balsam fIR CONTENT IN FOREST sucCEssion: Plots A-1 to A-7, Laniel: B-1 to B-12, Black Sturgeon: C-2 to C-6, Cedar Lake

\begin{tabular}{|c|c|c|c|c|c|c|c|c|c|c|}
\hline \multirow{3}{*}{ Plot } & \multicolumn{4}{|c|}{ Ratios of $\mathrm{Fb} / \mathrm{S}$} & \multicolumn{6}{|c|}{ Apparent trends of $\mathbf{F b}$ content 1} \\
\hline & \multirow{2}{*}{$\begin{array}{c}\begin{array}{c}\text { Trees In } \\
\text { original } \\
\text { stand }\end{array} \\
1950 \\
\end{array}$} & \multicolumn{3}{|c|}{ Reproduction } & \multicolumn{3}{|c|}{$\begin{array}{l}\text { Reproduction cf. } \\
\text { original stand } \\
\text { of trees }\end{array}$} & \multicolumn{3}{|c|}{$\begin{array}{l}\begin{array}{l}\text { Reproduction } \\
\text { cf. } \\
\text { reproduction }\end{array} \\
\end{array}$} \\
\hline & & 1950 & 1955 & 1961 & 1950 & 1955 & 1961 & $1955 /$ & $\begin{array}{c}1961 / \\
1950 \\
\end{array}$ & $\begin{array}{r}1961 / \\
1955 \\
\end{array}$ \\
\hline A-1 & $15: 1$ & $31: 1$ & $38: 1$ & $18: 1$ & I & I & I & $\mathbf{I}$ & $\mathrm{D}$ & D \\
\hline$A-2$ & $41: 1$ & 29:1 & $33: 1$ & 106:1 & $\mathbf{D}$ & $\mathrm{D}$ & $\mathbf{I}$ & $\bar{I}$ & I & I \\
\hline$A-3$ & $4: 1$ & $2: 1$ & $4: 1$ & $23: 1$ & $\mathrm{D}$ & $\mathrm{NC}$ & I & I & $\mathrm{I}$ & I \\
\hline$A-4$ & $28: 1$ & $6: 1$ & $13: 1$ & $3: 1$ & $\mathbf{D}$ & $\mathrm{D}$ & $\mathrm{D}$ & I & $\mathrm{D}$ & D \\
\hline A-5 & $13: 1$ & 1.3:1 & $12: 1$ & $1.2: 1$ & $\mathrm{D}$ & $\mathrm{D}$ & $\mathrm{D}$ & I & D & D \\
\hline A- 6 & $64: 1$ & $24: 1$ & All $\mathbf{F b}$ & 11:1 & $\mathrm{D}$ & I & D & $\mathbf{I}$ & D & D \\
\hline$A-7$ & $60: 1$ & $25: 1$ & $28: 1$ & $14: 1$ & $\mathrm{D}$ & D & D & I & D & $\mathrm{D}$ \\
\hline B-1 & $5: 1$ & $24: 1$ & $21: 1$ & $23: 1$ & I & I & I & $\mathrm{D}$ & D & I \\
\hline B-2 & $3: 1$ & $27: 1$ & $27: 1$ & $13: 1$ & I & I & I & $\mathrm{NC}$ & D & D \\
\hline B-3 & $0.9: 1$ & $39: 1$ & $37: 1$ & $28: 1$ & I & I & I & D & D & D \\
\hline B-4 & $8: 1$ & $13: 1$ & $12: 1$ & $11: 1$ & I & I & I & $\mathrm{D}$ & $\mathrm{D}$ & D \\
\hline$B-5 a$ & $24: 1$ & $83: 1$ & $56: 1$ & $32: 1$ & I & I & I & $\mathrm{D}$ & $\mathrm{D}$ & $\mathrm{D}$ \\
\hline B-5b & $26: 1$ & $120: 1$ & $112: 1$ & $70: 1$ & I & I & I & D & D & $\mathrm{D}$ \\
\hline$B-6 b$ & $5: 12$ & $67: 12$ & $71: 1$ & $5.5: 1$ & I & I & I & $\mathrm{D}$ & $\mathrm{D}$ & D \\
\hline B-7 & $2: 1$ & $29: 1$ & $26: 1$ & 19:1 & I & I & I & $\mathrm{D}$ & D & D \\
\hline B-8 & $4: 1$ & $12: 1$ & $13: 1$ & $6: 1$ & I & I & I & $\mathrm{D}$ & D & $\mathrm{D}$ \\
\hline B-9 & $2: 1$ & $17: 1$ & $14: 1$ & $12: 1$ & I & I & I & $\mathrm{D}$ & $\mathrm{D}$ & D \\
\hline B10 & $26: 1$ & $69: 1$ & $71: 1$ & $20: 1$ & I & $\bar{I}$ & $\bar{D}$ & I & $\overline{\mathrm{D}}$ & $\overline{\mathrm{D}}$ \\
\hline B-11 & $3: 1$ & $210: 1$ & $147: 1$ & $95: 1$ & I & I & I & $\mathrm{D}$ & $\mathrm{D}$ & $\bar{D}$ \\
\hline B-12 & $19: 1$ & All Fb & All Fb & All Fb & I & I & I & $\mathrm{NC}$ & $\mathrm{NC}$ & $\mathrm{NC}$ \\
\hline$C-2$ & $6: 1$ & $21: 1$ & $12: 1$ & $21: 1$ & I & I & I & D & $\mathrm{NC}$ & I \\
\hline C-3 & $3: 1$ & $9: 1$ & $7: 1$ & $9: 1$ & I & I & I & $\mathrm{D}$ & $\mathrm{NC}$ & I \\
\hline C-4 & $0.8: 1$ & $3: 1$ & $4: 1$ & $3.5: 1$ & I & $I$ & I & $\bar{I}$ & I & D \\
\hline C-5 & $2: 1$ & $7: 1$ & $5: 1$ & $4.5: 1$ & $I$ & $I$ & I & D & D & $\mathrm{D}$ \\
\hline C-6 & $40: 1$ & $20: 1$ & $13: 1$ & $11: 1$ & D & D & D & D & D & $\mathrm{D}$ \\
\hline
\end{tabular}

${ }^{I}$ I-Increasing; D-Decreasing: NC-No Change.

but there were proportionately greater increases in the numbers of spruce seedlings, thereby possibly affecting the balsam fir to spruce ratio. Part of the differences between the tallies in 1955 and 1961 are attributable to real changes in stand composition resulting from establishment of new seedlings and death of others. It should be borne in mind, however, that small sampling errors can distort the apparent stand composition considerably. For example, an average error of one seedling per milacre quadrat is equal to a difference of 1,000 seedlings per acre, which may easily nullify small changes in the ratios of balsam fir to spruce. Although great care was exercised to avoid such errors, the crowding of the seedlings on certain 
TABLE 2

ESTIMATED NUMBERS OF BALSAM FIR AND BLACK AND WHITE SPRUCE STEMS PER ACRE IN 1961

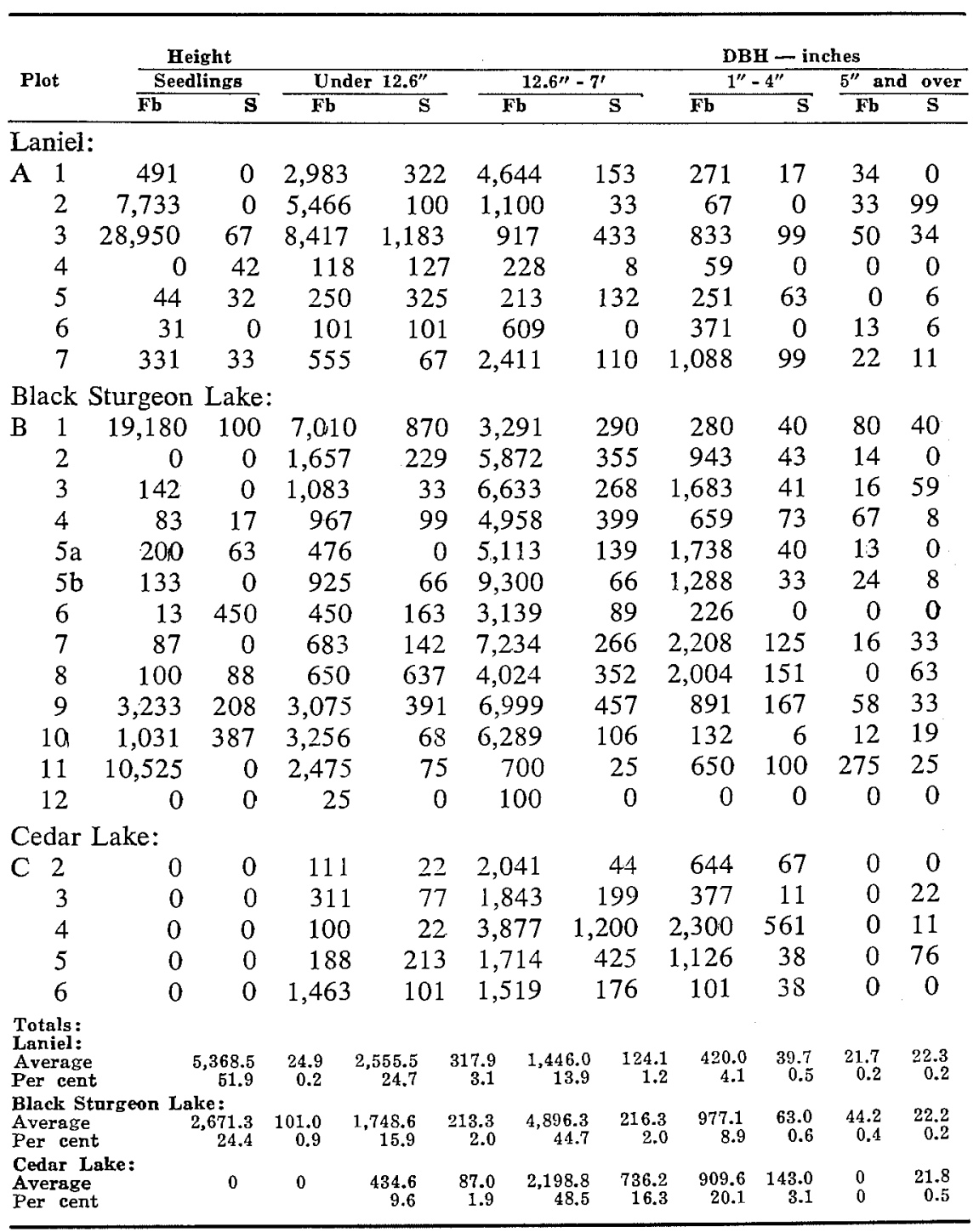


quadrats, as well as their concealment by herbs, shrubs, and brush, caused unavoidable errors. We feel that use of rigid boundaries for the quadrats in the latest tally removed some of the sampling error that was inherent in the earlier tallies.

\section{STAND COMPOSITION IN 1961}

The proportions of balsam fir and spruce stems per acre for the three areas are summarized in Table 2, and the regional percentages are presented as a bar-graph in Fig. 1. Where the percentage is too small to be presented

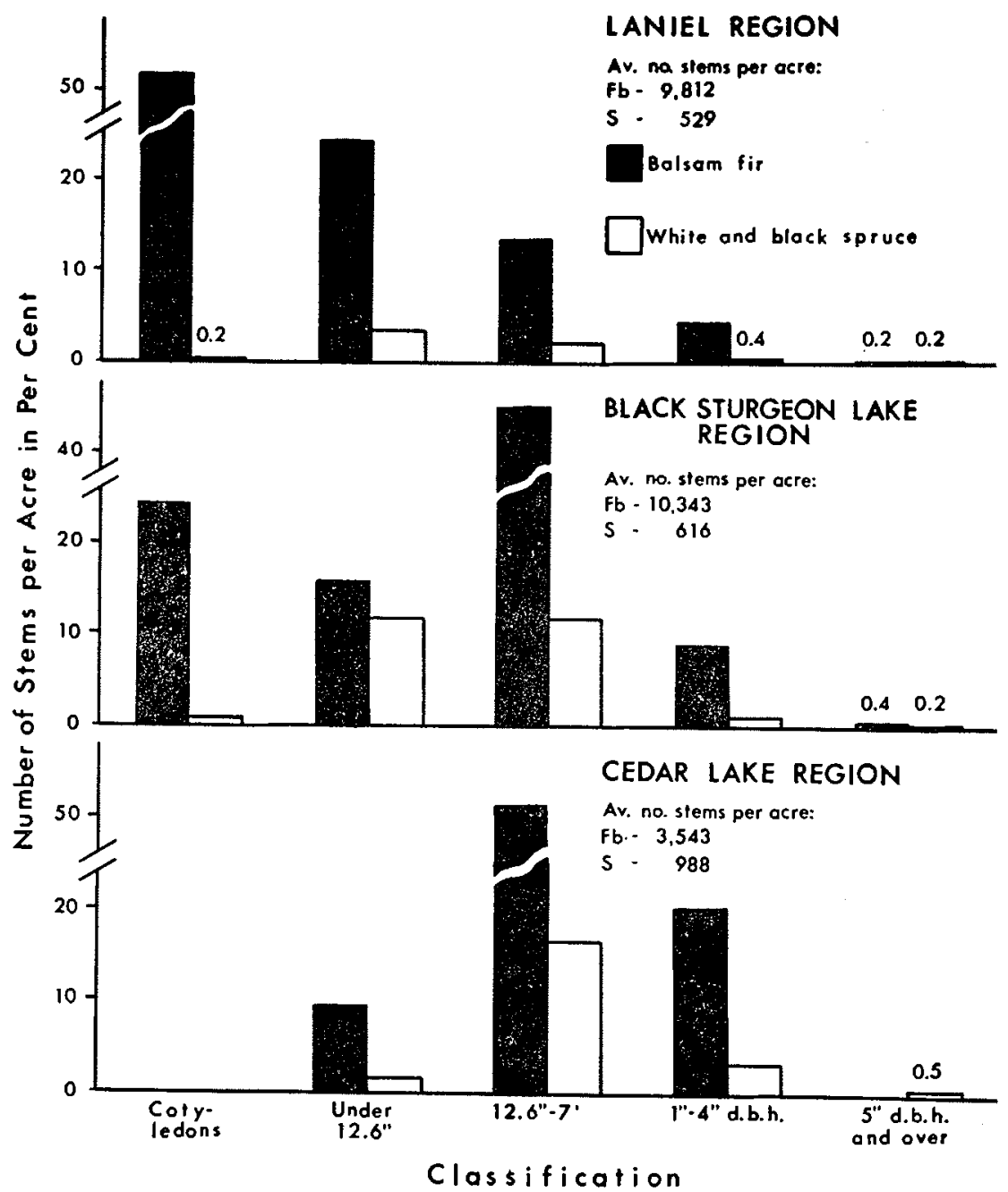

FIGURE 1. Number of stems per acre in height and diameter classes expressed as a per cent of the total number. ("Cotyledons" refers to first-year seedlings.) 
clearly in the figure, the actual percentage is entered in the appropriate column. The height and diameter classes in Table 2 were selected to emphasize the stratified structure of the stands.

During 1961, a careful watch was kept for seed production by trees in the reproduction classes accepted for this study. Although roadside balsam fir and spruce trees one to three inches in diameter were producing some seed by 1961, none were observed on the plots. It would appear, therefore, that any seedlings established since 1955 originated from residual trees that survived the budworm outbreak. Furthermore, the excellent seed crop in 1960 resulted in the establishment of a large number of seedlings in 1961 on certain plots where seed bed conditions were suitable. The tally of these seedlings appears in Table 2. Not all plots responded to a reasonably satisfactory supply of seed trees, but in no case were there many seedlings where the seed source was lacking or inadequate. This is particularly true at Cedar Lake, where there were no first-year seedlings in the tally. Regionally, 52 per cent of all the stems on the Laniel plots originated in 1961, 24 per cent on the Black Sturgeon Lake plots, and none on the Cedar Lake plots.

On certain Black Sturgeon Lake plots, a number of balsam fir trees in the 2and 3-inch diameter classes produced seed in 1962. Therefore, there will be an added source of seed to be considered in future analyses of reproduction.

The average heights of the balsam fir and spruce reproduction for each plot in each region, calculated from the distribution of stems by height classes, are listed in Table 3 for 1950, 1955, and 1961. The average increment for the 11-year period from 1950 to 1961 , and the average annual increment for this period are also included in the table. In 1961, all stems in the 1-inch diameter class were arbitrarily assigned a height of 8 feet for the purpose of calculating the average heights for the plots. The 1961 seedlings were not included in the computation.

Ghent (1958) showed that balsam fir seedlings at Black Sturgeon Lake responded to release by killing of the overstory with a fivefold increase over the previous mean annual height increment of 1.2 inches under suppressed conditions. Table 3, however, shows that the annual increment of 2.4 inches for released reproduction is only twice as great as it was under suppressed conditions. Although average height figures derived in this manner may have been useful when most of the reproduction was in the low height classes, they do not convey an accurate picture of the present vigour of the forest for several reasons. There are no actual height measurements for those trees in the 1- and 2-inch diameter class that have broken out of the general canopy and are adding the greatest yearly increment. These trees are now retarding the growth of the smaller stems growing within their shade and competing for the same root space. On the other hand, even after assigning a height of 8 feet to the 1-inch trees, their number is not large enough to counteract the depressing effect on the average annual increment of the more numerous, slower-growing stems.

Analysis of the 1961 data revealed the above effect of suppression, and additional measurements were accordingly made in August, 1962. Twenty trees, under conditions ranging from suppression to open-growing, were 
TABLE 3

Average Heights of Balsam fir and Spruce Reproduction in Inches

\begin{tabular}{|c|c|c|c|c|c|c|}
\hline \multirow{2}{*}{ PIot } & \multicolumn{3}{|c|}{ Balsam fir } & \multicolumn{3}{|c|}{ Spruce } \\
\hline & 1950 & 1955 & 1961 & 1950 & 1955 & 1961 \\
\hline \multicolumn{7}{|l|}{ Laniel: } \\
\hline A 1 & 4.0 & 12.7 & 22.1 & 5.0 & 1.4 & 9.2 \\
\hline 2 & 3.0 & 5.4 & 8.2 & 3.0 & 5.4 & 14.1 \\
\hline 3 & 13.2 & 16.7 & 10.6 & 13.8 & 19.6 & 14.0 \\
\hline 4 & 6.0 & 20.5 & 32.7 & 3.3 & 3.0 & 6.6 \\
\hline 5 & 12.1 & 25.0 & 43.0 & 5.2 & - & 23.4 \\
\hline 6 & 9.0 & 24.7 & 52.1 & 3.0 & - & 3.8 \\
\hline 7 & 10.7 & 29.0 & 51.9 & 19.0 & 36.3 & 45.1 \\
\hline $\bar{x}=$ & 8.3 & 19.1 & 31.5 & 7.5 & 13.1 & 16.6 \\
\hline \multicolumn{7}{|c|}{ Black Sturgeon Lake: } \\
\hline B 1 & 8.1 & 13.5 & 13.8 & 10.7 & 19.0 & 14.0 \\
\hline 2 & 12.0 & 23.6 & 33.6 & 19.5 & 33.6 & 30.2 \\
\hline 3 & 13.6 & 29.9 & 45.7 & 17.8 & 39.1 & 40.3 \\
\hline 4 & 11.3 & 24.0 & 34.3 & 11.1 & 20.2 & 28.9 \\
\hline $5 a$ & 8.9 & 30.6 & 52.7 & 14.8 & 33.7 & 49.1 \\
\hline $5 b$ & 7.0 & 22.7 & 41.8 & 8.6 & 23.3 & 30.2 \\
\hline 6 & 8.5 & 21.3 & 38.7 & 10.2 & 18.0 & 12.4 \\
\hline 7 & 9.6 & 37.0 & 51.4 & 17.9 & 40.5 & 43.1 \\
\hline 8 & 19.2 & 40.7 & 48.1 & 27.6 & 41.8 & 20.5 \\
\hline 9 & 17.5 & 24.4 & 29.6 & 25.1 & 24.4 & 25.2 \\
\hline 10 & 4.6 & 10.1 & 21.4 & 7.5 & 20.4 & 17.4 \\
\hline 11 & 15.7 & 16.5 & 19.4 & 一 & 36.0 & 30.6 \\
\hline 12 & 6.5 & 17.7 & 55.1 & - & - & 一 \\
\hline$\vec{x}=$ & 11.0 & 24.0 & 37.4 & 15.5 & 29.2 & 28.5 \\
\hline \multicolumn{7}{|c|}{ Cedar Lake: } \\
\hline C 2 & 14.9 & 36.0 & 54.6 & 17.4 & 22.9 & 59.2 \\
\hline 3 & 12.9 & 22.0 & 40.5 & 17.0 & 21.6 & 28.6 \\
\hline 4 & 21.0 & 44.3 & 63.1 & 21.1 & 41.1 & 52.5 \\
\hline 5 & 32.0 & 36.9 & 59.3 & 13.3 & 20.9 & 23.1 \\
\hline 6 & 6.0 & 9.5 & 19.8 & 14.8 & 13.6 & $23 . a$ \\
\hline $\bar{x}=$ & 17.4 & 29.7 & 49.3 & 16.7 & 24.0 & 37.3 \\
\hline \multirow{2}{*}{\multicolumn{2}{|c|}{ Region }} & \multicolumn{2}{|c|}{$\begin{array}{c}\text { Average Increment } \\
1950-1961 \\
\end{array}$} & & \multicolumn{2}{|c|}{$\begin{array}{c}\text { Average Annual } \\
\text { Xrerement } 1950-1961\end{array}$} \\
\hline & & Fb & $\mathbf{S}$ & & $\mathrm{Fb}$ & $\mathrm{s}$ \\
\hline \multirow{3}{*}{\multicolumn{2}{|c|}{$\begin{array}{l}\text { Laniel } \\
\text { Black Sturgeon } \\
\text { Cedar Lake }\end{array}$}} & 23.2 & 9.1 & & 2.1 & 0.8 \\
\hline & & 26.4 & 13.0 & & 2.4 & 1.2 \\
\hline & & 32.1 & 20.6 & & 2.9 & 1.9 \\
\hline
\end{tabular}


selected from each of the height classes and from the 1- and 2-inch diameter classes used in tallying. All the trees were on or within the peripheries of four of the regeneration plots at Black Sturgeon Lake. The annual height increment was measured to the nearest 0.1 inch for the 10-year period from 1953 to 1962 . In a few cases it was impossible to obtain the full 10 measurements because the criteria used to separate years were not always distinct on the suppressed stems. The average 10-year and annual increment for each height class up to 7 feet and for 1- and 2-inch diameter trees are listed in Table 4. The average annual increments are plotted in Fig. 2. The table and graph present a clear picture of the actual growth rates of balsam fir and spruce in the Black Sturgeon Lake Region, and demonstrate the competitive ability of the two species at this stage of development. The annual increments of 2.4 and 1.2 inches for balsam fir and spruce, respectively, represent the growth rates of trees under 3 feet in height. The growth rate of these small trees, which are suppressed by the 1-inch and 2-inch trees, places them in much the same category as the suppressed reproduction of the mature stand before the budworm outbreak. The larger trees, owing to their rapid growth, will form the next merchantable stand. Many of the suppressed trees will die and be replaced by new seedlings developing from seed from the larger trees. There was some evidence of loss of smaller trees in 1962, since a number of them located in thickets of larger trees had red foliage by August. Very few instances of this were seen in 1961.

TABLE 4

Height InCREment in Inches for Balsam fir and Spruce FOR 1953-1962 AT BLACK STURGEON LAKE

\begin{tabular}{ccccc}
\hline $\begin{array}{c}\text { Height or } \\
\text { Diameter } \\
\text { Class }\end{array}$ & \multicolumn{2}{c}{$\begin{array}{c}\text { Average increment } \\
\text { for }\end{array}$} & 1953-1962 & \multicolumn{2}{c}{$\begin{array}{c}\text { Aversge annual } \\
\text { increment }\end{array}$} \\
\hline $0-6.5^{\prime \prime}$ & 6.6 & 7.2 & Fb & S \\
\hline $6.6-12.5^{\prime \prime}$ & 7.6 & 9.8 & 0.66 & 0.72 \\
$12.6-18.5^{\prime \prime}$ & 12.1 & 11.9 & 0.76 & 0.98 \\
$2^{\prime}$ & 19.0 & 16.0 & 1.21 & 1.19 \\
$3^{\prime}$ & 26.5 & 25.5 & 1.90 & 1.60 \\
$4^{\prime}$ & 34.5 & 33.1 & 2.65 & 2.55 \\
$5^{\prime}$ & 45.9 & 40.1 & 3.45 & 3.31 \\
$6^{\prime}$ & 51.9 & 49.8 & 4.59 & 4.01 \\
$7^{\prime}$ & 63.6 & 61.3 & 5.19 & 4.98 \\
1" $^{\prime \prime}$ & $84.6 . h$. & 75.2 & 6.36 & 6.13 \\
2 $^{\prime \prime}$ & 132.4 & 117.3 & 8.47 & 7.52 \\
\end{tabular}




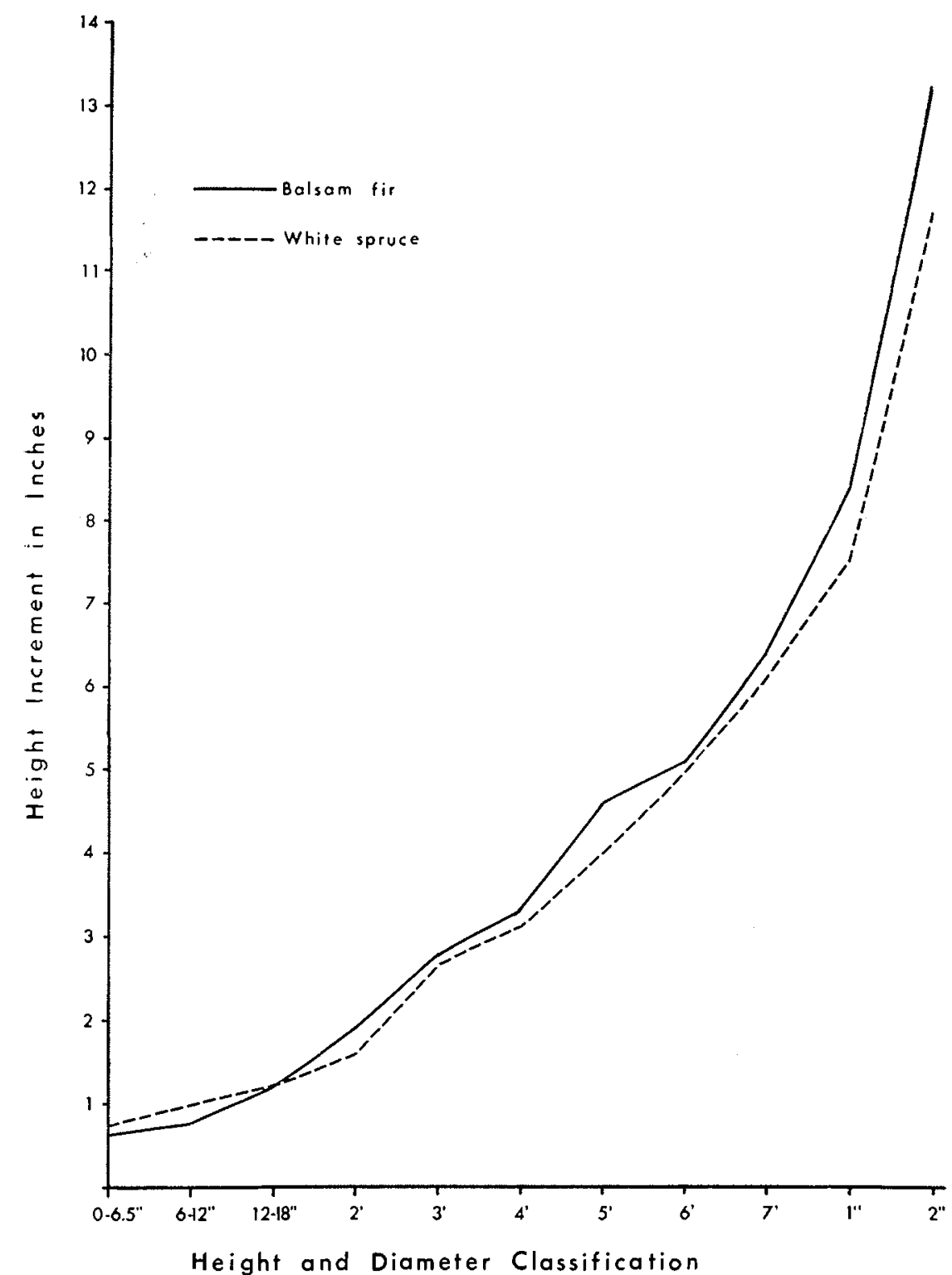

FIGURE 2. Average annual height increments of balsam fir and white spruce for 1953 to 1962. 


\section{Discussion}

The two major objectives of the long-term study of stand development following a severe spruce budworm outbreak stated by Ghent et al. (1957) were: (1) to determine, from a comparison of the ratio of balsam fir to spruce in the new stands with the corresponding ratio in the devastated stands, if some factor in the budworm attack favoured balsam fir regeneration over spruce, and (2) to ascertain the age and origin of the regeneration in relation to the spruce budworm outbreak. Ghent et al. (1957) and Ghent (1958) showed that the spruce budworm itself provides the mechanism for release of established seedlings. For instance, it was shown conclusively in one area following the outbreak that the majority of the balsam fir seedlings had been accumulating during the previous 20 to 30 years. This was further substantiated by the fact that cone production ceased shortly after the start of defoliation. In providing a release, therefore, a spruce budworm attack affects the next forest no differently than do other major disturbances such as cutting or fire. Hatcher (1960) studied the development of balsam fir following a clearcutting operation in Quebec between 1941 and 1944, and showed that there were from 1,400 to 2,000 fir seedlings per acre 15 years after cutting. These seedlings had developed into fully-stocked sapling stands 15 years after the cutting operations. We should now consider our studies not only from the point of view of what effect the spruce budworm has on forest succession, but also to answer the question, "Can these data be used in deciding what represents adequate stocking as related to composition at particular points in the history of a stand in order to obtain a merchantable stand at least equal to the previous one?" Changes in the apparent trends of balsam fir content (Table 1) indicate the danger of attempting to forecast future stand composition at the present time.

By way of summary, changes that have occurred since the inception of this project in 1950 may be described as follows: Upon removal of the overstory by defoliation, nearly all the established reproduction responded by increased height growth. Very soon, however, competition began from invading shrubs, particularly mountain maple, hazel, and raspberry, and affected some stems more than others. Differences in development increased when the overstory of dead balsam fir and spruce fell down, killing some seedlings, retarding others, and releasing still others from shrub competition. These factors, along with the continuous influx of new seedlings from seed from residual trees, have produced a stand with ever-increasing variability in vigour, which is mainly reflected in differential height growth. As mentioned earlier, the stands in 1961 gave an impression of a vigorous, fast-growing forest, but when reproduction in all height classes was considered in calculating mean heights and mean annual increments, this impression was masked. The 1962 measurements of the comparative growth rate over the past ten years placed the growth rates of the reproduction in the various height and diameter classes in their proper perspective.

The larger trees are now beginning to compete with each other, and to crowd out those less vigorous or reduce them to a mere survival status. Are there now enough vigorous stems to provide a merchantable stand? What will be the rate of depletion of the understory seedlings and their 
rate of replacement? Numerous ramifications of these questions could be posed, but the answers can be provided only as the present regeneration matures. We now have records of the stocking of the original stands that were destroyed by the spruce budworm, and three periodic tallies of the reproduction forming the new stands on these same areas. We know when the latter originated, and we have a record of the comparative growth rates of balsam fir and spruce reproduction over the past ten years. These data provide a sound base on which to add the results of future surveys. We believe that this paper, together with the two earlier contributions on this subject (Ghent et al. 1957, Ghent, 1958), clearly demonstrates the role the spruce budworm has played in the development of the stands under consideration. Research will continue on the status of the budworm at the endemic population levels prevailing between outbreaks. At the same time, more intensified silvical studies of the balsam fir-spruce stands should be carried on by the appropriate research groups. These studies should investigate the rate of growth of the reproduction and its survival under various competitive conditions to assist in the intepretation of long-term trends in forest succession. A considerable amount of research has been carried out in Quebec and New Brunswick concerning the development of balsam fir stands. These studies have included stand development following cutting (Hatcher, 1960) the response of immature balsam and spruce to release from shrub competition (Baskerville, 1961) and to crown release (Baskerville, 1961a); and the development of balsam fir following the spruce budworm outbreak of 1913-1919 (Vincent, 1962). This research in many instances was concerned with stands in a stage of development not yet reached by the stands in the Black Sturgeon Lake region. The data already available for the Black Sturgeon Lake plots will be invaluable as a basis for future silvical studies since previously it has often been necessary to obtain basic information of this type by retrogressive interpretation of data from more mature stands. An attempt should be made to provide as soon as possible a forecast of when the balsam fir should reach an economical cutting size so as to assist companies with large holdings of this type in long-term planning.

\section{ACKNOWLEDGEMENTS}

The authors wish to thank their colleagues at the Forest Insect Laboratory, Sault Ste. Marie, for reviewing the manuscript. 


\section{REFERENCES}

BASKERVILLE, G. L. 1961. Response of young fir and spruce to release from shrub competition. Canada, Department of Forestry, For. Res. Div., Tech. Note No. 98.

BASKERVILLE, G. L. 1961a. Development of immature balsam fir following crown release. Canada, Department of Forestry, For. Res. Div., Tech. Note No. 101.

GHENT, A. W., D. A. FRASER, and J. B. THOMAS. 1957. Studies of regeneration of forest stands devastated by the budworm. I. Evidence of trends in forest succession during the first decade following budworm devastation. For. Sci. 3:184-208.

GHENT, A. W. 1958. Studies of regeneration of forest stands devastated by the budworm. II.Age, height growth and related studies of balsam fir seedlings. For. Sci. 4:135-146.

GHENT, A. W. 1963. Studies of regeneration in forest stands devastated by the spruce budworm. III. Problems of sampling precision and seedling distribution. For. Sci. 9:295-310.

HATCHER, R. J. 1960. Development of balsam fir following a clear cut in Quebec. Canada Dept. of Northern Affairs and National Resources, Forestry Branch, For. Res. Div., Tech Note No. 87.

HILLS, G. A. 1959. A ready reference to the description of the land of Ontario and its productivity. Research Branch, Ontario Department of Lands and Forests. 142 pp.

VINCENT, A. B. 1962. Development of balsam fir thickets in the Green River watershed following the spruce budworm outbreak of 1913-1919. Canada Dept. of Forestry, For. Res. Branch, Tech. Note No. 119. 